\title{
A review of the efficacy of mitomycin $C$ in glaucoma filtration surgery
}

\author{
This article was published in the following Dove Press journal: \\ Clinical Ophthalmology \\ 20 October 2015 \\ Number of times this article has been viewed
}

\section{Ahmed Al Habash ${ }^{1,2}$ \\ Leyla Ali Aljasim' \\ Ohoud Owaidhah' \\ Deepak P Edward ${ }^{1,3}$}

'King Khaled Eye Specialist Hospital, Riyadh, Kingdom of Saudi Arabia; ${ }^{2}$ Department of Ophthalmology, University of Dammam, Dammam, Saudi Arabia; ${ }^{3}$ Wilmer Eye Institute, Johns Hopkins University School of Medicine, Baltimore, MD, USA
Correspondence: Deepak P Edward King Khaled Eye Specialist Hospital, PO Box 7I9I, Riyadh II462, Saudi Arabia

Tel +966 I | 482 I 234 ext 2055

Fax +966 I| 482 I908

Email dedward@kkesh.med.sa
Abstract: The success of trabeculectomy, which is considered the gold standard in the surgical treatment of glaucoma, depends on the wound healing response. The introduction of antiproliferative agents such as mitomycin C (MMC) has increased the success rates of trabeculectomy. However, complications due to these agents can be challenging to manage. Hence, it is important to determine the most efficacious dose and duration of exposure. Multiple studies suggest that many factors, including but not limited to MMC preparation, different concentrations, different exposure times, and method of application may affect success rate, and these factors were reviewed in this article. We concluded that lower concentrations of MMC that are prepared and applied in a standardized fashion, such as that using the Mitosol ${ }^{\circledR}$ kit (for 2-3 minutes) during trabeculectomy, could potentially provide trabeculectomy success rates similar to that reported with off-label preparations, and that such a treatment regime could result in in lower complication rates than higher doses of MMC.

Keywords: mitomycin C, Mitosol, filtering surgery, trabeculectomy, outcomes

\section{Introduction}

The goal of glaucoma surgery is to reduce intraocular pressure, which decreases the likelihood and rate of visual field loss in susceptible patients. ${ }^{1}$ Currently, there are a number of surgical options for reducing intraocular pressure in glaucoma that include incisional surgery, non-penetrating filtration surgery, glaucoma drainage devices, and minimally invasive glaucoma surgeries.

The challenge of surgeries that require external fistulization is reactive scarring and abnormal wound healing of the subconjunctival space that lowers long-term success. ${ }^{2}$ Numerous approaches have been used to prevent conjunctival fibrosis after filtering surgery. Currently, the cytotoxic antimetabolites, 5-fluorouracil and mitomycin $\mathrm{C}$ (MMC), are the most commonly used agents. ${ }^{3}$ Other agents that have been used to prevent postoperative scarring include anti-vascular endothelial growth factor antibodies, ${ }^{4}$ tumor growth factor beta antibodies, ${ }^{3}$ and Ologen ${ }^{\circledR}$ implants. ${ }^{5}$ However, these agents were either ineffective as yet, or there is limited evidence to suggest that they might replace MMC. Despite many innovative approaches, MMC remains the most frequently used agent due to its reasonable efficacy in preventing subconjunctival fibrosis.

This review outlines the efficacy of various MMC preparations including the widely use concentration of $0.2 \mathrm{mg} / \mathrm{mL}$ of MMC prepared as an off-label product in a vial and a recently available kit, and compares it with other concentrations and exposure times of MMC.

\section{Role of filtration surgery in glaucoma}

Cairns introduced trabeculectomy in $1968 .{ }^{6}$ Over time, trabeculectomy has become the most common surgical procedure for glaucoma and is considered the gold standard 
for the surgical management of glaucoma. A survey of the American and Japanese Glaucoma Societies published in 1997 reported trabeculectomy was the preferred initial surgical approach for both societies. ${ }^{7}$ Successful trabeculectomy requires a fistula that diverts aqueous humor into the subconjunctival space. The main challenge postoperatively is to minimize scarring in the subconjunctival space by reducing inflammation and by slowing or halting the healing process. Long-term follow-up of primary trabeculectomy without adjunctive MMC indicates that despite successful control of intraocular pressure (1OP) at 1 year, the probability of success decreases with time and stabilizes at $67 \%$ by 10 years. ${ }^{8} \mathrm{Chen}^{9}$ described the efficacy of MMC in enhancing bleb survival following trabeculectomy in eyes with a high risk of failure. A 2004 survey of British ophthalmology consultants reported that $82 \%$ used antimetabolites during trabeculectomy. ${ }^{10}$ MMC was the most commonly used antimetabolite among American Glaucoma Society members in 2008. ${ }^{11}$

\section{Efficacy of mitomycin solution in glaucoma filtration surgery}

MMC was isolated in Japan in 1954 from the broth of the Streptomyces caespitosus. MMC is an alkylating agent that prevents DNA synthesis. Its pharmacological effect is likely due to the quinone, carbamate, and aziridine groups that comprise the molecule. MMC undergoes metabolic activation via reduction into an alkylating agent, a process mediated by cytochrome $\mathrm{P}-450$ reductase and that occurs most effectively in a hypoxic environment. ${ }^{12}$ Additionally, data available from the antitumor activity of MMC, including biochemical and cell-based experiments, demonstrate that the enzyme NQO1 can also bioactivate MMC and is generally a good predictor of MMC sensitivity. ${ }^{13}$ However, there are a host of factors that can influence the antitumor response to MMC that include intracellular $\mathrm{pH}$ and oxygen concentrations, competing bioreductive enzymes, and DNA repair enzymes responsible for the repair of cytotoxic MMC-DNA interstrand crosslinks. Hence, it is unlikely that studying only the NQO1 genotype or NQO1 protein levels will predict a MMC-related clinical response to tumor suppression or anti-fibrotic activity. ${ }^{13}$

In a study on human Tenon's capsule tissue, MMC caused almost complete inhibition of fibroblast proliferation. ${ }^{14} \mathrm{How}-$ ever, many factors can influence the efficacy of MMC as it interacts with fibroblasts. ${ }^{14,15}$ These factors include the dose delivered to the tissues (which is concentration dependent), volume, duration of exposure, preparation method, administration, and tissue-related factors. ${ }^{14}$ In vitro study of Tenon's capsule cultures suggests that fibroblast inhibition due to MMC is mainly dependent on the concentration and that a sponge applied for 1 minute can be as effective as a sponge applied for 5 minutes. ${ }^{14,15}$ Clinical studies have observed that tissue becomes saturated with MMC after exposure for 1 minute. ${ }^{16}$ Additionally, control of IOP was similar whether MMC was used for 2 minutes or 5 minutes. ${ }^{17,18}$

The effects of MMC concentration on the success of glaucoma surgery are discussed in this review. The method of MMC application to tissue may also influence the effectiveness. Flynn et $\mathrm{al}^{19}$ compared microsurgical sponges from Alcon Laboratories, Inc (Fort Worth, TX, USA), Meroce ${ }^{\circledR}$ (Medtronic, Inc, Dublin, Leinster, UK), Storz Medical AG (Tuttlingen, Germany), and Weck-Cel ${ }^{\circledR}$ (XOMED Surgical Products, Inc, Jacksonville, FL, USA) for MMC application. They reported that the Weck-Cel brand demonstrated intermediate values for both the maximum volume absorbed and expansion widths of the sponge after the sponge was soaked in MMC. These sponges also released the largest amount of MMC. ${ }^{19}$ The authors concluded that variability in drug delivery characteristics observed in vitro suggested that type of microsurgical sponge may be an important factor in MMC delivery to the tissues. ${ }^{19}$

Another factor that might influence the efficacy of $\mathrm{MMC}$ is the area of tissue that comes in contact with MMC. Application of MMC over a larger surface area achieves a higher short-term decrease in IOP and a significantly lower incidence of bleb scarring compared to eyes that receive MMC application over a smaller area. ${ }^{20-22}$ The site and time of MMC application might also influence fibroblast inhibition. Traditionally, MMC has been applied into sub-Tenon's space intraoperatively, with some surgeons also placing it beneath the scleral flap. Applying MMC-soaked sponges before creating the scleral flap or beneath the scleral flap, and other variations in surgical technique, could influence the outcome of trabeculectomy beyond the influence of the concentration and duration of MMC application. ${ }^{23,24}$

Furthermore, studies have suggested that intrascleral application of MMC might be as efficacious as subconjunctival application. ${ }^{23-25}$ Recently, MMC has been used as a single preoperative subconjunctival injection in various low-dose concentrations prior to trabeculectomy. ${ }^{26,27}$ Though this technique appears to have gained popularity, there are no peer-reviewed publications that suggest that this method of application is superior to other techniques. An additional factor that may play a role in lowering IOP following application of MMC during trabeculectomy is MMC toxicity to the ciliary epithelium. Histopathological studies in human eyes 
and experimental studies have demonstrated toxic effects of MMC to the ciliary body and its epithelium, which likely cause a reduction in aqueous secretion and a lowering of IOP. ${ }^{28,29}$ Patient variables beyond those presented in this paper may influence surgical outcomes. These include thickness of Tenon's capsule, degree of tissue vascularity and bleeding, and possibly, different receptor responses to $\mathrm{MMC}$. $^{3}$

\section{Clinical studies on the effectiveness of mitomycin C}

The adjunctive use of MMC has been a major advance in the efficacy of lowering IOP with trabeculectomy. However, there are complications associated with MMC use, including hypotony and maculopathy in the early postoperative period. Many investigators have attempted to develop protocols for adjunctive therapy that allow an acceptable balance between the risks and benefits. ${ }^{9-11,18}$

A previous study has suggested that the level of inhibition of fibroblast proliferation correlated with the outcome of filtering surgery. ${ }^{30} \mathrm{~A}$ clinical trial has supported the benefit of $\mathrm{MMC}$ as an adjunct to trabeculectomy. ${ }^{31}$ An in vivo confocal microscopy study displayed that the final effect of the filtering procedure with $\mathrm{MMC}$ was a fivefold increase in conjunctival microcyst density and surface area on the site of the bleb. ${ }^{32}$ Intraoperative treatments with MMC result in long term inhibition of fibroblast proliferation with abnormal marked variation in cell size and vacuoles in the cytoplasm limited to the treated area, when compared with intraoperative and postoperative treatment with $5-\mathrm{FU} .{ }^{33}$ A recent qualitative and quantitative analysis comparing filtering blebs with optical coherence tomography showed that blebs following MMC trabeculectomy had good functionality with low index of reflectivity and cystoid pattern. On the other hand, in trabeculectomies without MMC, mixed optical coherence tomography patterns (layer or diffuse pattern) were associated with high infrared and poor functionality. ${ }^{34}$

MMC can enhance the success rate of trabeculectomy for refractory glaucoma in patients of most ethnic backgrounds, including those of African ancestry. ${ }^{35-42}$ Enhanced success rates have also been reported in glaucoma associated with uveitis, congenital and developmental glaucoma, normal-tension glaucoma, and primary, uncomplicated trabeculectomies. ${ }^{35-42}$

A Cochrane database review of eleven clinical trials evaluating 698 patients concluded that MMC reduced the risk of surgical failure in eyes undergoing primary trabeculectomy and high-risk eyes. ${ }^{43}$ A study of primary trabeculectomy with low-dose MMC reported that IOP was maintained at
$15 \mathrm{mmHg}$ or less in more than $80 \%$ of patients after 1 year and in $60 \%$ of patients after 6 years. ${ }^{44} \mathrm{~A}$ study with a majority of patients at high risk of failure reported that $0.2 \mathrm{mg} / \mathrm{mL}$ of MMC for 5 minutes resulted in an 84\% success rate at 1 year follow-up. ${ }^{45}$ Annen and Stürmer ${ }^{46}$ used $0.2 \mathrm{mg} / \mathrm{mL} \mathrm{MMC} \mathrm{for}$ 1 minute and noted an IOP of $<21 \mathrm{mmHg}$ in $88 \%$ of cases at approximately 1 year, with $8.8 \%$ of cases developing an avascular bleb.

In a prospective, randomized study, Kitazawa et $\mathrm{al}^{47}$ reported that $88 \%$ of glaucomatous eyes with poor surgical prognosis achieved an $1 \mathrm{OP}$ of $\leq 20 \mathrm{mmHg}$ without glaucoma medications after MMC during trabeculectomy, while only $47 \%$ of eyes receiving 5-fluorouracil achieved a similar outcome in a period of 7-12 months. Similarly, Skuta et al' ${ }^{48}$ randomized study of eyes at high risk for failure from glaucoma filtering surgery reported that $60 \%$ of MMCtreated eyes had an IOP of $\leq 12 \mathrm{mmHg}$ versus only $21.1 \%$ of 5-fluorouracil-treated eyes at 6 months.

Singh et $\mathrm{al}^{49}$ evaluated a consecutive series of 20 eyes that underwent trabeculectomy with $0.02 \mathrm{mg} / \mathrm{mL} \mathrm{MMC}$ intraoperatively and reported an overall success rate of $85 \%$. In this series, there were two cases of recurrent leaks and two cases of scleral necrosis exposing the ciliary body. ${ }^{49}$ The authors cautioned that such complications, though rare, can occur with lower doses of MMC, and they recommended that lower doses of MMC or placing MMC in the sub-Tenon's space without scleral dissection could potentially avoid the complication of scleral necrosis. Furthermore, another study suggested that based on the successful outcome of trabeculectomy with MMC, its use may be justified in primary trabeculectomies in patients with advanced glaucoma. ${ }^{44}$ In pediatric patients who underwent trabeculectomy with $\mathrm{MMC}$, the success rates varied from $56 \%$ to $95 \% .{ }^{50-52}$

Additionally, administration of MMC during filtering surgery often leads to development of thin-walled, avascular blebs, which might result in bleb leaks that predispose eyes to infection. ${ }^{53,54}$ There may be an increased risk of developing a thin-walled bleb with higher concentrations of MMC. ${ }^{55}$

High-dose MMC can be associated with complications. Akova et $\mathrm{al}^{56}$ reported two cases of scleromalacia in pediatric patients who received $0.4 \mathrm{mg} / \mathrm{cc}$ MMC for 5 minutes. Fourman $^{57}$ reported a case series of five patients who developed scleritis 3 to 24 weeks after adjunctive MMC during inferior trabeculectomy.

MMC has also been used with success as an adjunct to needling and non-penetrating glaucoma surgery. Using MMC during needling a failed filtering bleb resulted in an $85 \%$ success rate. ${ }^{58}$ In a retrospective study, Mardelli et al ${ }^{59}$ 
reported that MMC needle revision is an effective method to revive failed filtration surgery in terms of IOP reduction. Trials have also shown that intraoperative MMC during deep sclerectomy results in lower IOPs ${ }^{60,61}$ However, MMC in glaucoma drainage devices does not seem to affect the outcome of the surgical procedure during Molteno ${ }^{\circledR}$ valve $^{62,63}$ or Ahmed glaucoma valve implantation. ${ }^{64,65}$

Based on the literature and our current review, it appears that reducing $\mathrm{MMC}$ dosage or exposure time of intraoperative MMC may mitigate the incidence of complications associated with overfiltration and perhaps, may also avoid the development of ischemic blebs.

\section{Clinical observations on the surgical outcomes using different concentrations of mitomycin $\mathbf{C}$}

Prospective and retrospective studies have addressed the effectiveness of various concentrations of MMC on the outcome of glaucoma filtration surgery. However, the conclusions regarding effects of $\mathrm{MMC}$ concentration and exposure time are variable, and these observations are summarized in this section (later).

Robin et $\mathrm{al}^{66}$ evaluated four groups: placebo, $0.2 \mathrm{mg} / \mathrm{mL}$ MMC for 2 minutes, $0.2 \mathrm{mg} / \mathrm{mL}$ MMC for 4 minutes, and $0.4 \mathrm{mg} / \mathrm{mL} \mathrm{MMC}$ for 2 minutes, respectively, with 1-year follow-up. They concluded that a possible dose-response relationship exists between efficacy and the concentration and duration of exposure to MMC. ${ }^{66}$ Kitazawa et al ${ }^{67}$ evaluated 0.02 and $0.2 \mathrm{mg} / \mathrm{mL}$ MMC in primary trabeculectomy and reported $63.6 \%$ and $100 \%$ success rates, respectively, with transient hypotony maculopathy $(18 \%)$ and cataract progression (18\%) noted in the $0.2 \mathrm{mg} / \mathrm{mL}$ group exclusively. The authors suggested that the appropriate dose was between the two concentrations. ${ }^{67}$ Laube et al ${ }^{68}$ evaluated $0.1,0.2$, and $0.4 \mathrm{mg} / \mathrm{mL}$ of MMC for 2.5 minutes, and found that $0.2 \mathrm{mg} / \mathrm{mL}$ was the most effective dose.

Alternately, other studies have reported that altering the exposure time had little to no effect on postoperative IOP reduction or success rates of trabeculectomy. ${ }^{17,18}$ Sanders et $\mathrm{al}^{69}$ confirmed that filtering surgery performed on higher risk eyes was as effective at a lower dose $(0.2 \mathrm{mg} / \mathrm{mL})$ of MMC compared to a higher dose $(0.4 \mathrm{mg} / \mathrm{mL})$. They reported a higher incidence of hypotony-related complications with the higher concentration $(0.4 \mathrm{mg} / \mathrm{mL})$ group. ${ }^{69}$ Maquet et $\mathrm{al}^{70}$ used three different concentrations of MMC $(0.1 \mathrm{mg} / \mathrm{mL}, 0.2 \mathrm{mg} / \mathrm{mL}$, and $0.4 \mathrm{mg} / \mathrm{mL})$ and found no significant differences in IOP control and postoperative complications. Lee et al ${ }^{71}$ compared $0.4 \mathrm{mg} / \mathrm{mL}, 0.2 \mathrm{mg} / \mathrm{mL}$, and $0.1 \mathrm{mg} / \mathrm{mL}$ MMC in 36 eyes and found no statistical difference in IOP reduction between concentrations. They noted postoperative hypotony in only two patients, both from the $0.4 \mathrm{mg} / \mathrm{mL}$ group. ${ }^{71} \mathrm{~A}$ recent prospective, randomized trial with 2 years' follow-up demonstrated the non-inferiority of $0.1 \mathrm{mg} / \mathrm{mL}$ of MMC compared to $0.2 \mathrm{mg} / \mathrm{mL} .^{72}$

The use of MMC in pediatric glaucoma has also been studied. Agarwal et al ${ }^{73}$ reported that MMC $0.4 \mathrm{mg} / \mathrm{mL}$ and $0.2 \mathrm{mg} / \mathrm{mL}$ were equally effective in post-trabeculectomy patients with congenital glaucoma. They also reported that $0.2 \mathrm{mg} / \mathrm{mL}$ MMC resulted in a lower incidence of thin-walled blebs, postoperative hypotony, wound leakage, and choroidal detachments. ${ }^{73}$ Most studies of prolonged MMC application report an increased risk of postoperative complications. ${ }^{16,74,75}$ However, this observation remains controversial. ${ }^{18}$

A retrospective, comparative study on patients at high risk for failure reported that surgical success at 18 months postoperatively with $0.2 \mathrm{mg} / \mathrm{mL}$ MMC for 2 minutes was similar to a matched group receiving $0.2 \mathrm{mg} / \mathrm{mL}$ MMC for 5 minutes. ${ }^{18}$ In combined trabeculectomy with phacoemulsification and intraocular lens implantation with MMC $0.5 \mathrm{mg} / \mathrm{mL}$ applications of 1,3 , or 5 minutes, the IOP outcomes were similar. ${ }^{76}$

In addition to the benefits of lowering IOP, MMC-assisted trabeculectomy may have an impact on the patient's quality of life (QoL). The Collaborative Initial Glaucoma Treatment Study (CIGTS) compared the outcome of medical treatment to initial MMC trabeculectomy. ${ }^{77}$ At 5 years follow-up, both medical and surgical therapy were effective in reducing IOP, but initial surgery led to lower visual field progression in subjects with advanced visual field loss at baseline. ${ }^{77}$ However, the risk of cataract formation after trabeculectomy was higher, resulting in a decrease in vision-related QoL. ${ }^{77}$ Most, but not all, vision QoL subscales indicated worsening of cataracts prior to cataract surgery and an improvement in vision after cataract extraction. ${ }^{78}$ A French study reported that poor vision-related QoL was associated with topical drug side effects..$^{79}$ A recent report on quality-adjusted lifeyears and the incremental cost-effectiveness ratio reported that glaucoma surgeries such as trabeculectomy and tube insertion were determined to be cost-effective compared with medical therapy alone, and that trabeculectomy had a lower cost per quality-adjusted life-year compared with tube insertion. ${ }^{80}$ Though the cost effectiveness of trabeculectomy has been addressed in studies discussed earlier, the direct and indirect costs associated with a failed trabeculectomy and its comparison with a primary trabeculectomy with Mitosol $^{\circledR}$ (Mobius Therapeutics, LLC, St Louis, MO, USA) remain unknown. Future studies are likely to address this issue.

In summary, most studies appear to suggest that lower concentrations of MMC and shorter exposure times are as 
effective in achieving lower IOPs when compared to higher concentrations/prolonged exposure times. In contrast, higher MMC concentrations and prolonged exposure times may be associated with a higher risk of complications. Some variability in the study outcomes related to MMC concentration and exposure time might be dependent on study design, patient selection, and outcome measures.

\section{Preparation of mitomycin C}

$\mathrm{MMC}$ is customarily frozen in storage and thawed to room temperature before use or prepared on site from a vial. The use of different concentrations of MMC requires on-site preparation under suboptimal conditions and can lead to dosage errors. ${ }^{81}$ The potency of MMC after storage has been studied in vitro. ${ }^{82}$ High-performance liquid chromatography evaluation indicated that MMC had similar stability, despite different preparations and storage methods, if it was used immediately upon reaching room temperature. ${ }^{83}$ However, some degradation of MMC occurred with further storage at room temperature, and the clinical effects of this degradation are unclear. ${ }^{83}$ Additionally, on-site formulation can result in an unstable solution, due to incorrect $\mathrm{pH}$ or storage temperatures. ${ }^{84}$

The off-label application of MMC in glaucoma surgery has been quite effective. However, many variables may affect the stability and efficacy of MMC when prepared on site compared to a compounding pharmacy. Recently, the US Food and Drug Administration (FDA) approved MMC for ab externo glaucoma surgery. The preparation is available in a $0.2 \mathrm{mg} / \mathrm{vial}$ concentration, with standardized sponges packaged in a kit (Mitosol). The advantages of this kit include reliable potency prepared in optimal conditions, proper dosing, sterility, and an extended shelf life at room temperature. Additionally, standardized sponges are included in the kit as the size, type, and shape of the sponge might influence the efficacy of MMC. ${ }^{19,85}$ A standard number of sponges are included to eliminate human error when counting used sponges during surgery. No clinical studies were conducted for FDA approval of Mitosol. FDA approval was based on the efficacy of MMC in open-angle glaucoma reported in the existing body of literature. ${ }^{86}$

The availability of a standardized preparation of MMC is a welcome addition in the armamentarium of adjunctive therapy in glaucoma filtration surgery. However, there are some controversial aspects to the introduction of this preparation. For example, there have been no randomized clinical trials comparing the Mitosol kit to MMC prepared in a compounding pharmacy. MMC at $0.2 \mathrm{mg} / \mathrm{mL}$ is the most common concentration for glaucoma surgery. However, higher concentrations of MMC may be preferred for cases of repeat trabeculectomy or inflammatory glaucoma. ${ }^{70}$ Furthermore, this preparation may not be available in developing countries. The most controversial aspect of this preparation is the substantial increase in the cost of the surgical procedure. The cost of one Mitosol kit is reportedly US\$359, which is several-fold more expensive than the offlabel preparation of MMC (depending on the country). ${ }^{86}$ This issue is similar to the debate on the cost-effectiveness of ophthalmic bevacizumab versus ranibizumab in the treatment of retinal disease. ${ }^{87}$

\section{Conclusion}

Surgical intervention plays a major role in the management of glaucoma. Trabeculectomy with adjunctive MMC application intraoperatively increases surgical success. Standardization of different variables during trabeculectomy has been investigated for several years and has been discussed in detail in this review. The efficacy of $0.2 \mathrm{mg} / \mathrm{mL}$ of MMC applied for a period of 2-3 minutes during surgery appears to be quite effective in clinical trials. However, prospective studies are warranted to determine the efficacy of standardized preparations of MMC, such as Mitosol. Standardized kits such as Mitosol are likely to result in faster surgery while mitigating dosage errors, maintaining aseptic conditions, and preventing other intraoperative errors, such as retained sponges. The issue of cost of standardized preparations needs to be addressed, especially if the goal is worldwide distribution.

\section{Disclosure}

The authors report no conflicts of interest in this work.

\section{References}

1. Heijl A, Leske MC, Bengtsson B, Hyman L, Bengtsson B, Hussein M. Early Manifest Glaucoma Trial Group. Reduction of intraocular pressure and glaucoma progression: results from the Early Manifest Glaucoma Trial. Arch Ophthalmol. 2002;120(10):1268-1279.

2. Husain R, Clarke JC, Seah SK, Khaw PT. A review of trabeculectomy in East Asian people - the influence of race. Eye (Lond). 2005;19(3): 243-225.

3. Lama PJ, Fechtner RD. Antifibrotics and wound healing in glaucoma surgery. Surv Ophthalmol. 2003;48(3):314-346.

4. Grewal DS, Jain R, Kumar H, Grewal SP. Evaluation of subconjunctival bevacizumab as an adjunct to trabeculectomy a pilot study. Ophthalmology. 2008;115(12):2141-2145.

5. Cillino S, Di Pace F, Cillino G, Casuccio A. Biodegradable collagen matrix implant vs mitomycin-C as an adjuvant in trabeculectomy: a 24-month, randomized clinical trial. Eye (Lond). 2011;25(12): 1598-1606.

6. Cairns JE. Trabeculectomy. Preliminary report of a new method. Am J Ophthalmol. 1968;66(4):673-679.

7. Chen PP, Yamamoto T, Sawada A, Parrish RK 2nd, Kutazawa Y. Use of antifibrosis agents and glaucoma drainage devices in the American and Japanese glaucoma societies. J Glaucoma. 1997;6(3):192-196.

8. Chen TC, Wilensky JT, Viana MA. Long-term follow-up of initially successful trabeculectomy. Ophthalmology. 1997;104(7):1120-1125. 
9. Chen CW. Enhanced intraocular pressure controlling effectiveness of trabeculectomy by local application of mitomycine-C. Trans Asia-Pacific Acad Ophthalmol. 1983;9:172-173.

10. Siriwardena D, Edmunds B, Wormald RP, Khaw PT. National survey of antimetabolite use in glaucoma surgery in the United Kingdom. Br J Ophthalmol. 2004;88(7):873-876.

11. Desai MA, Gedde SJ, Feuer WJ, Shi W, Chen PP, Parrish RK. Practice preferences for glaucoma surgery: a survey of the American Glaucoma Society in 2008. Ophthalmic Surg Lasers Imaging. 2011;42(3):202-208.

12. Salmon SE, Sartorelli AC. Cancer chemotherapy. In: Katsung BG, editor. Basic and Clinical Pharmacology. Norwalk, CT: Appleton and Lange; 1987:680-681.

13. Siegel D, Yan C, Ross D. NAD(P)H:quinone oxidoreductase 1 (NQO1) in the sensitivity and resistance to antitumor quinones. Biochem Pharmacol. 2012;83(8):1033-1040.

14. Jampel HD. Effect of brief exposure to mitomycin $\mathrm{C}$ on viability and proliferation of cultured human Tenon's capsule fibroblasts. Ophthalmology. 1992;99(9):1471-1476.

15. Yamamoto T, Varani J, Soong HK, Lichter PR. Effects of 5-fluorouracil and mitomycin $\mathrm{C}$ on cultured rabbit subconjunctival fibroblasts. Ophthalmology. 1990;97(9):1204-1210.

16. Zacharia PT, Deppermann SR, Schuman JS. Ocular hypotony after trabeculectomy with mitomycin C. Am J Ophthalmol. 1993;116(3):314-326.

17. Manners T, Salmon JF, Barron A, Willies C, Murray AD. Trabeculectomy with mitomycin $\mathrm{C}$ in the treatment of post-traumatic angle recession glaucoma. Br J Ophthalmol. 2001;85(2):159-163.

18. Mégevand GS, Salmon JF, Scholtz RP, Murray AD. The effect of reducing the exposure time of mitomycin $\mathrm{C}$ in glaucoma filtering surgery. Ophthalmology. 1995;102(1):84-90.

19. Flynn WJ, Carlson DW, Bifano SL. Mitomycin trabeculectomy: the microsurgical sponge difference. J Glaucoma. 1995;4(2):86-90.

20. Matlach J, Panidou E, Grehn F, Klink T. Large-area versus small-area application of mitomycin C during trabeculectomy. Eur J Ophthalmol. 2013;23(5):670-677

21. Cordeiro MF, Constable PH, Alexander RA, Bhattacharya SS, Khaw PT. Effect of varying the mitomycin-C treatment area in glaucoma filtration surgery in the rabbit. Invest Ophthalmol Vis Sci. 1997;38(8): 1639-1646.

22. Onol M, Aktaş Z, Hasanreisoglu B. Enhancement of the success rate in trabeculectomy: large-area mitomycin-C application. Clin Experiment Ophthalmol. 2008;36(4):316-322.

23. Agarwal HC, Saigal D, Sihota R. Assessing the role of subconjunctival versus intrascleral application of mitomycin-C in high-risk trabeculectomies. Indian J Ophthalmol. 2001;49(2):91-95.

24. Tressler CS, Cyrlin MN, Rosenshein JS, Fazio R. Subconjunctival versus intrascleral mitomycin-C in trabeculectomy. Ophthalmic Surg Lasers. 1996;27:661-666.

25. Zhang M, Li B, Wang J, Liu W, Wu X. Subconjunctival versus intrascleral application of mitomycin $\mathrm{C}$ during trabeculectomy. Invest Ophthalmol Vis Sci. Epub 2014 Jul 21.

26. Ghoneim EM, Abd-El Ghny AA, Gab-Allah AA, Kamal MZ. Preoperative subconjunctival injection of mitomycin $\mathrm{C}$ versus intraoperative topical application as an adjunctive treatment for surgical removal of primary pterygium. Middle East Afr J Ophthalmol. 2011;18(1):37-41.

27. Hung PT, Lin LL, Hsieh JW, Wang TH. Preoperative mitomycin-C subconjunctival injection and glaucoma filtering surgery. $J$ Ocul Pharmacol Ther. 1995;11(3):233-241.

28. Schraermeyer U, Diestelhorst M, Bieker A, et al. Morphologic proof of the toxicity of mitomycin $\mathrm{C}$ on the ciliary body in relation to different application methods. Graefes Arch Clin Exp Ophthalmol. 1999; 237(7):593-600.

29. Nuyts RM, Felten PC, Pels E, et al. Histopathologic effects of mitomycin $\mathrm{C}$ after trabeculectomy in human glaucomatous eyes with persistent hypotony. Am J Ophthalmol. 1994;118(2):225-237.

30. Madhavan HN, Rao SB, Vijaya L, Neelakantan A. In vitro sensitivity of human Tenon's capsule fibroblasts to mitomycin C and its correlation with outcome of glaucoma filtration surgery. Ophthalmic Surg. 1995;26(1):61-67.
31. Bergstrom TJ, Wilkinson WS, Skuta GL, Watnick RL, Elner VM. The effect of subconjunctival mitomycin-C on glaucoma filtration surgery in rabbits. Arch Ophthalmology. 1991;109(12):1725-1730.

32. Ciancaglini M, Carpineto P, Agnifili L, et al. Conjunctival characteristics in primary open-angle glaucoma and modifications induced by trabeculectomy with mitomycin $\mathrm{C}$ : an in vivo confocal microscopy study. Br J Ophthalmol. 2009;93(9):1204-1209.

33. Khaw PT, Sherwood MB, Doyle JW, et al. Intraoperative and post-operative treatment with 5-fluorouracil and mitomycin-c: long term effects in vivo on subconjunctival and scleral fibroblasts. Int Ophthalmol. 1992;16(4-5):381-385.

34. Napoli PE, Zucca I, Fossarello M. Qualitative and quantitative analysis of filtering blebs with optical coherence tomography. Can J Ophthalmol. 2014;49(2):210-216.

35. Palanca-Capistrano AM, Hall J, Cantor LB, Morgan L, Hoop J, WuDunn D. Long term outcomes of intraoperative 5-fluorouracil versus intraoperative mitomycin $\mathrm{C}$ in primary trabeculectomy surgery. Ophthalmology. 2009;116(2):185-190.

36. Mermoud A, Salmon JF, Murray AD. Trabeculectomy with mitomycin C for refractory glaucoma in blacks. Am J Ophthalmology. 1993; 116(1):72-78.

37. Prata JA Jr, Neves RA, Minckler DS, Mermoud A, Heuer DK. Trabeculectomy with mitomycin $\mathrm{C}$ in glaucoma associated with uveitis. Ophthalmic Surg. 1994;25(9):616-620.

38. Susanna R Jr, Oltrogge EW, Carani JC, Nicolela MT. Mitomycin as adjunct chemotherapy with trabeculectomy in congenital and developmental glaucomas. J Glaucoma. 1995;4(3):151-157.

39. Yamamoto T, Ichien M, Suemori-Matsushita H, Kitazawa Y. Trabeculectomy for normal tension glaucoma. Nippon Ganka Gakkai Zasshi. 1994;98(6):579-583. Japanese.

40. Costa VP, Moster MR, Wilson RP, Schmidt CM, Gandham S, Smith M. Effects of topical mitomycin C on primary trabeculectomies and combined procedures. Br J Ophthalmol. 1993;77(11):693-697.

41. Mirza GE, Karaküçük S, Doğan H, Erkiliç K. Filtering surgery with mitomycin $\mathrm{C}$ in uncomplicated (primary open angle) glaucoma. Acta Ophthalmol. 1994;72(2):155-161.

42. Kupin TH, Juzych MS, Shin DH, Khatana AK, Olivier MM. Adjunctive mitomycin C in primary trabeculectomy in phakic eyes. Am JOphthalmol. 1995;119(1):30-39.

43. Wilkins $\mathrm{M}$, Indar $\mathrm{A}, \mathrm{W}$ ormald R. Intra-operative mitomycin $\mathrm{C}$ for glaucoma surgery [review]. Cochrane Database Syst Rev. 2005;4:CD002897.

44. Beckers HJ, Kinders KC, Webers CA. Five year results of trabeculectomy with mitomycin c. Graefes Arch Clin Exp Ophthalmol. 2003; 241(2):106-110.

45. Palmer SS. Mitomycin as adjunct chemotherapy with trabeculectomy. Ophthalmology. 1991;98(3):317-321.

46. Annen DJ, Stürmer J. [Follow-up of a pilot study of trabeculectomy with low dosage mitomycin $\mathrm{C}(0.2 \mathrm{mg} / \mathrm{mL}$ for 1 minute). Independent evaluation of a retrospective nonrandomized study]. Klin Monbl Augenheilkd. 1995;206(5):300-302. German.

47. Kitazawa Y, Kawase K, Matsushita H, Minobe M. Trabeculectomy with mitomycin: a comparative study with fluorouracil. Arch Ophthalmol. 1991;109(12):1693-1698.

48. Skuta GL, Beeson CC, Higginbotham EJ, et al. Intraoperative mitomycin versus postoperative 5- fluorouracil in high-risk glaucoma filtering surgery. Ophthalmology. 1992;99(3):438-444.

49. Singh J, O'Brien C, Chawla HB. Success rate and complications of intraoperative $0.2 \mathrm{mg} / \mathrm{mL}$ mitomycin $\mathrm{C}$ in trabeculectomy surgery. Eye (Lond). 1995;9(Pt 4):460-466.

50. Mandal AK, Walton DS, John T, Jayagandan A. Mitomycin C-augmented trabeculectomy in refractory congenital glaucoma. Ophthalmology. 1997;104(6):996-1001.

51. Wallace DK, Plager DA, Synder SK, Raiesdana A, Helveston EM, Ellis FD. Surgical results of secondary glaucomas in childhood. Ophthalmology. 1998;105(1):101-111.

52. Beck AD, Wilson WR, Lynch MG, Lynn MJ, Noe R. Trabeculectomy with adjunctive mitomycin $\mathrm{C}$ in pediatric glaucoma. Am J Ophthalmol. 1998;126(5):648-657. 
53. Greenfield DS, Suñer IJ, Miller MP, Kangas TA, Palmberg PF, Flynn HW Jr. Endophthalmitis after filtering surgery with mitomycin. Arch Ophthalmol. 1996;114(8):943-949.

54. Soltau JB, Rothman RF, Budenz DL, et al. Risk factors for glaucoma filtering bleb infections. Arch Ophthalmol. 2000;118(3):338-342.

55. DeBry PW, Perkins TW, Heatley G, Kaufman P, Brumback LC. Incidence of late-onset bleb-related complications following trabeculectomy with mitomycin. Arch Ophthalmol. 2002;120(3):297-300.

56. Akova YA, Koç F, Yalvaç I, Duman S. Scleromalacia following trabeculectomy with intraoperative mitomycin C. Eur J Ophthalmol. 1999; 9(1):63-65.

57. Fourman $\mathrm{S}$. Scleritis after glaucoma filtering surgery with mitomycin $\mathrm{C}$. Ophthalmology. 1995;102(10):1569-1571.

58. Gutiérrez-Ortiz C, Cabarga C, Teus MA. Prospective evaluation of preoperative factors associated with successful mitomycin $\mathrm{C}$ needling of failed filtration blebs. J Glaucoma. 2006;15(2):98-102.

59. Mardelli PG, Lederer CM Jr, Murray PL, Pastor SA, Hassanein KM. Slit-lamp needle revision of failed filtering blebs using mitomycin C Ophthalmology. 1996;103(11):1946-1955.

60. Kozobolis VP, Christodoulakis EV, Tzanakis N, Zacharopoulos I, Pallikaris IG. Primary deep sclerectomy versus primary deep sclerectomy with the use of mitomycin $\mathrm{C}$ in primary open-angle glaucoma. J Glaucoma. 2002;11(4):287-293.

61. Anand N, Kumar A, Gupta A. Primary phakic deep sclerectomy augmented with mitomycin C: long-term outcomes. J Glaucoma. 2011; 20(1):21-27.

62. Lee D, Shin DH, Birt CM, et al. The effect of adjunctive mitomycin C in Molteno implant surgery. Ophthalmology. 1997;104(12):2126-2135.

63. Cantor L, Burgoyne J, Sanders S, Bhavnani V, Hoop J, Brizendine E. The effect of mitomycin $\mathrm{C}$ on Molteno implant surgery: a 1-year randomized, masked, prospective study. J Glaucoma. 1998;7(4):240-246.

64. Kurnaz E, Kubaloglu A, Yilmaz Y, Koytak A, Ozertürk Y. The effect of adjunctive mitomycin $\mathrm{C}$ in Ahmed glaucoma valve implantation. Eur J Ophthalmol. 2005;15(1):27-31.

65. Costa VP, Azuara-Blanco A, Netland PA, Lesk MR, Arcieri ES. Efficacy and safety of adjunctive mitomycin $\mathrm{C}$ during Ahmed glaucoma valve implantation: a prospective randomized clinical trial. Ophthalmology. 2004;111(6):1071-1076

66. Robin AL, Ramakrishnan R, Krishnadas R, et al. A long-term doseresponse study of mitomycin in glaucoma filtration surgery. Arch Ophthalmol. 1997;115(8):969-974.

67. Kitazawa Y, Suemori-Matsushita H, Yamamoto T, Kawase K. Low-dose and high-dose mitomycin trabeculectomy as an initial surgery in primary open-angle glaucoma. Ophthalmology. 1993;100(11):1624-1628.

68. Laube T, Ritters B, Selbach M, Hudde T. [Clinical experiences and results of mitomycin C in trabeculectomy]. Klin Monbl Augenheilkd. 2003;220(9):618-624. German.

69. Sanders SP, Cantor LB, Dobler AA, Hoop JS. Mitomycin C in higher risk trabeculectomy: a prospective comparison of $0.2-$ to $0.4-\mathrm{mg} / \mathrm{cc}$ doses. J Glaucoma. 1999;8(3):193-198.

70. Maquet JA, Dios E, Aragón J, Bailez C, Ussa F, Laguna N. Protocol for mitomycin C use in glaucoma surgery. Acta Ophthalmol Scand. 2005;83(2):196-200.

71. Lee JJ, Park KH, Youn DH. The effect of low- and high-dose adjunctive mitomycin C in trabeculectomy. Korean J Ophthalmol. 1996;10(1): $42-47$.

Clinical Ophthalmology

\section{Publish your work in this journal}

Clinical Ophthalmology is an international, peer-reviewed journal covering all subspecialties within ophthalmology. Key topics include: Optometry; Visual science; Pharmacology and drug therapy in eye diseases; Basic Sciences; Primary and Secondary eye care; Patient Safety and Quality of Care Improvements. This journal is indexed on Submit your manuscript here: http://www.dovepress.com/clinical-ophthalmology-journal
72. Sihota R, Angmo D, Chandra A, Gupta V, Sharma A, Pandey RM Evaluating the long-term efficacy of short-duration $0.1 \mathrm{mg} / \mathrm{mL}$ and $0.2 \mathrm{mg} / \mathrm{mL}$ MMC in primary trabeculectomy for primary adult glaucoma. Graefes Arch Clin Exp Ophthalmol. 2015;253(7):1153-1159.

73. Agarwal HC, Sood NN, Sihota R, Sanga L, Honavar SG. Mitomycin-C in congenital glaucoma. Ophthalmic Surg Lasers. 1997;28(12):979-985.

74. Cohen JS, Novack GD, Li ZL. The role of mitomycin treatment duration and previous intraocular surgery on the success of trabeculectomy surgery. J Glaucoma. 1997;6(1):3-9.

75. Kim YY, Sexton RM, Shin DH, et al. Outcomes of primary phakic trabeculectomies without versus with 0.5 - to 1 -minute versus 3- to 5-minute mitomycin C. Am J Ophthalmol. 1998;126(6):755-762.

76. Shin DH, Simone PA, Song MS, et al. Adjunctive subconjunctival mitomycin C in glaucoma triple procedure. Ophthalmology. 1995;102(10): $1550-1558$

77. Musch DC, Gillespie BW, Lichter PR, Niziol LM, Janz NK; CIGTS Study Investigators. Visual field progression in the Collaborative Initial Glaucoma Treatment Study the impact of treatment and other baseline factors. Ophthalmology. 2009;116(2):200-207.

78. Musch DC, Gillespie BW, Niziol LM, et al; Collaborative Initial Glaucoma Treatment Study Group. Cataract extraction in the collaborative initial glaucoma treatment study: incidence, risk factors, and the effect of cataract progression and extraction on clinical and quality-of-life outcomes. Arch Ophthalmol. 2006;124(12):1694-1700.

79. Nordmann JP, Auzanneau N, Ricard S, Berdeaux G. Vision related quality of life and topical glaucoma treatment side effects. Health Qual Life Outcomes. 2003;1:75.

80. Kaplan RI, De Moraes CG, Cioffi GA, Al-Aswad LA, Blumberg DM. Comparative cost-effectiveness of the Baerveldt implant, trabeculectomy with mitomycin, and medical treatment. JAMA Ophthalmol. 2015;133(5):560-567.

81. Francoeur AM, Assalian A, Lesk MR, et al. A comparative study of the chemical stability of various mitomycin C solutions used in glaucoma filtering surgery. J Glaucoma. 1999;8(4):242-246.

82. Georgopoulos M, Vass C, VatanparastZ, Wolfsberger A, Georgopoulos A. Activity of dissolved mitomycin $\mathrm{C}$ after different methods of long-term storage. J Glaucoma. 2002;11(1):17-20.

83. Kinast RM, Akula KK, DeBarber AE, et al. The degradation of mitomycin C under varioussStorage methods. J Glaucoma. Epub 2015 May 14.

84. Velpandian T, Saluja V, Ravi AK, et al. Evaluation of the stability of extemporaneously prepared ophthalmic formulation of mitomycin C. J Ocul Pharmacol Ther. 2005;21(3):217-222.

85. Mehel E, Weber M, Stork Vabres L, Pechereau A. [Does the dosage of mitomycin-C applied during filtering surgery of glaucoma vary with the individual surgeon?]. J Fr Ophtalmol. 1997;20(3):195-199. French.

86. No authors listed. Mitomycin solution (Mitosol) for glaucoma surgery. Med Lett Drugs Ther. 2013;55(1412):24.

87. Dakin HA, Wordsworth S, Rogers CA; IVAN Study Investigators. Cost-effectiveness of ranibizumab and bevacizumab for age-related macular degeneration: 2-year findings from the IVAN randomised trial. BMJ Open. 2014;4(7):e005094.

PubMed Central and CAS, and is the official journal of The Society of Clinical Ophthalmology (SCO). The manuscript management system is completely online and includes a very quick and fair peer-review system, which is all easy to use. Visit http://www.dovepress.com/ testimonials.php to read real quotes from published authors. 